\title{
The World Before Her: A Review
}

\author{
Akanksha Mehta* \\ *Correspondence: [akanksha_mehta@soas.ac.uk]
}

I'd like to begin at the end.

As Nisha Pahuja's engaging documentary, The World Before Her, winds down, the protagonists are seen leaving the two spaces that were the focus of the film. Ruhi Singh, the aspiring Miss India, departs from the beauty pageant boot camp and competition and flies to her hometown of Jaipur. Heart broken and sullen after her loss, she walks out of the airport clouded in loneliness and is met by her father. A few hundred kilometres away, in another part of the state of Maharashtra, the Hindu nationalist camp organised for young girls and women by Durga Vahini (The Army of Durga) also concludes. The young leader of the camp, Prachi Trivedi, slows down, her resolute and aggressive persona giving way to quiet contemplation. As she ponders over her future in the Hindutva movement, the young girls leave the camp amidst loud and prolonged goodbyes. Numbers are exchanged, promises to meet are made, hugs are traded, and the girls enthusiastically wave to one another as cars take them away from the camp to their homes.

How did a camp organised by an exclusionary nationalist right-wing movement that was teaching young girls to perpetuate communal violence and imbibing them with hatred become a space for friendship and intimacy to flourish? How do we reconcile the politics of those loving long goodbyes with the politics of violence that the documentary showcased a mere few frames ago? On the other end, how does a competition that reduces a group of young women to an indistinguishable collective of bodies in identical clothing and make-up (so much so that in one scene the protagonist Ruhi Singh's parents are unable to locate her in a group photo of all the Miss India contestants) allow for the emergence of individual subjectivities and a multiplicity of stories, narratives, and emotions? It is these kinds of questions, contradictions, and tensions that contain the brilliance of The World Before Her. Nisha Pahuja's film not only compels the viewer to register the details of these two 'worlds' available to Indian women but also allows her to leave the screening with new questions and unseen answers.

The film opens with a snapshot of the life of Miss India contestants moving headlong into preparation for the big competition. Ruhi Singh, a nineteen year old contestant from Jaipur, appears confident and determined, telling the camera that she wanted to win the competition to make her parents proud. Wanting to live a life where she was 'free' and able to make her 
own choices, she had left her small town in search of opportunities in the fashion and beauty industry. In particularly poignant scenes we meet her parents who are fully supportive of her choices, looking out for her newspaper appearances (and later on, watching the competition on television) with excitement. At the beauty pageant boot camp, young women from all over the country are thrown into the world of fitness training, gym workouts, beauty, hair, and make-up consultants, diction experts, ramp-walk trainers, fashion designers, and cosmetic surgeons. With an attitude that can be best summarised by the dialogue - "It hurts? It looks fab!"- they are painfully sculpted into identical bodies that must give perfunctory answers with the perfect intonation. But as the film draws deeper into life at the boot-camp, the viewer gets glimpses into the multiple stories - full of vulnerability, insecurities, and strength - behind their flawless exteriors. Ruhi, plagued by anxiety about the competition, sits on the balcony crying and calling her parents for reassurance. Ankita, hesitant to wear a bikini in public, wonders how far she is willing to go to get the crown. Pooja, the former Miss India, narrates the heart-breaking story of her father and his family rejecting her at birth because of her sex. Another contestant speaks of how her father sent her to live in a Buddhist monastery when she was very young. Although her story drew astonished laughs from the audience, it connects to the rest in similar ways. These young women were in search of forms of independence, freedom, choice, and equality in a country that they often saw as suffocating and limiting. As they navigated the beauty industry in carefully crafted and instrumental ways, they were also simultaneously reduced to subjects of patriarchy and neoliberalism that capitalised on their bodies and dehumanised them regularly.

In what seems like a world away, we meet Prachi Trivedi, a young member and teacher of the Hindu nationalist women's organisation Durga Vahini (The Army of Durga). Established in the early 1990s the organisation adheres to the larger right-wing Hindu nationalist ideology, embracing the idea of a Bharat (India) where Hindus are given an elevated status and minority groups such as Muslims and Christians are excluded and suppressed. Key to organising and running a residential training camp for young girls held at a local school, Prachi tells the viewer of her long involvement in the movement, voicing her hatred for "weak figures like Gandhi" and her espousal of violence for the benefit of the nation. The camp, a part of a carefully crafted system of similar gatherings at various levels (national, regional, district, and local), aims to impart intellectual, spiritual, and physical education to girls (between the ages of 18 and 35) to transform them into strong and moral members of the Hindutva movement. Through Pahuja's coverage of the camp we see the nuances and aesthetics of the daily rituals and everyday politics of this gendered Hindu nationalist space. The trainees are made to wake up early and partake in rigorous exercises and prayers in the school ground as the saffron nationalist flag sways with the wind and a photograph of Bharat Mata (the Mother Goddess represented cartographically on a map of the 
subcontinent) glistens in front of them. They then take lessons on various topics - from their spiritual duties as daughters and wives-to-be to morality and mythology to holding guns and learning martial arts. Scholars such as Yuval-Davis (1997) have elaborated in depth on the intersections of gender and nationalism. Women are not only the reproducers and symbolic markers of nations and nationalisms but are also the imparters of moral and family values these movements espouse. As the documentary unfolds its scenes of pedagogical practices and strategies of this Hindu nationalist women's organisation, the aforementioned arguments of feminist scholars come alive. However, looking at the strategic and laborious formulation of the training programmes (as well as the inclusion of physical training, warrior goddesses, 'feminised' histories and aesthetics, and even career counselling for the girls), the film also compels the viewer to ask - are the teachers in the camp merely holding on to their 'natural' roles of mothers/educators or are they challenging these assigned roles and male-dominated discourses and reshaping Hindutva? Is there space for gendered (or even feminist) dissent within the Hindu nationalist project?

Although we hear from some of the members of this camp (including a young girl who takes great pride in not having any Muslim friends) and witness their blossoming friendships, Prachi shines as the protagonist tying the scenes from the Hindu nationalist camp together. Strong and confident, at a point in the film she looks into the camera and utters that she would kill for Hindutva and harm anyone that goes against her nation. But alongside her tough exterior that screams at and terrifies the girls in the camp and learns to fight with aggression, the film portrays the contradictions and gendered conundrums that occupy her mind. Prachi's father, a staunch and easily dislikeable patriarch who takes great pride at telling the viewers that he has used physical punishments to discipline his precious daughter, wants her to get married and have a family. Prachi, wanting to devote her life to Hindutva and the Hindu nation, longs for freedom and wants to achieve it by fighting for a belief system and ideology that is entrenched in patriarchy. Prachi goes through the film jokingly shutting down her father's aspirations for her while being visibly anxious and teary about these expectations. Perplexed by gendered norms, in a delightfully queer moment in the film, she laments that she is neither a girl nor a boy and she simply does not know how to be either. Her personal tensions and contradictions pointing to political ones for the movement itself.

While these 'two worlds' seem disconnected at first, the documentary's juxtaposition of them draws unnerving and interesting parallels. On an interview in a green rural Maharashtra, Prachi Trivedi tells the viewers that she is alright with her father hitting her as "he let her live" in spite of her being a girl child. A few scenes apart, the mother of former Miss India Pooja Sharma, tearfully speaks of giving birth to Pooja, a girl, and being asked to kill the baby by her husband and in-laws. Refusing to commit 
infanticide, she leaves her husband, raising her daughter alone. The undertone of patriarchal control (in personal, public, and political spheres) connect the two stories in concrete ways forcing the viewer to ask - how different are these worlds really? The embodied nature of this control in the two spaces further solidifies this connection. As women in the Hindu nationalist camp train their bodies in preparation for self-defence, reducing themselves to exercise counts and objects of martial arts manoeuvres, in a particularly dehumanising scene, women in the Miss India boot-camp walk down a beach, their faces and bodies covered with white cloths, only their legs visible as objects of the shoot. Women's bodies in both these worlds are rendered sites of control and objectification but as these bodies train for larger goals (Hindutva or Miss India), do they also become sites of subversion, agency, and bargains? Alongside patriarchy, the film also (mildly) engages with neoliberalism as a force that is re-shaping the lives of Indian women. The Hindutva movement embraces neoliberalism in the name of 'development' and the movement's women are now being trained to build respectable careers alongside becoming wives and mothers. Their aspirations (voiced by Prachi in particular) resonating sometimes with the latte-sipping Miss India contestants that embrace globalisation and cosmopolitanism with ease. Finally, in both these spaces, the viewer can locate the numerous everyday bargains and negotiations with patriarchy that these women undertake to find their space in an India that has room for many worlds. (Kandiyoti, 1988) Bargains that allow them agency and even partial empowerment in systems that were built on patriarchy. But how far will these negotiations and bargains take them in their quest for freedom? What shape does this freedom take?

As Miss India contestants glide on stage with their sashes, dresses, and high-heels, exhibiting the results of their beauty and fitness regimes and answering mundane (and often ridiculous) questions with poise; Pahuja takes us back to the Hindu Nationalist camp. The young girls get dressed in white outfits with saffron sashes, ready to participate in a public parade of their training. They joke that the sashes make them feel like beauty pageant contestants. They walk through the city's streets, holding banners, beating drums, showing off their swords and guns, singing and shouting slogans, and marking their gendered nationalist space in the public domain. Both these parades while focusing on the women of the film, show the viewer glimpses of the audiences. And it is in these glimpses of those excluded from a film about Indian women that one can ask the final questions - What other worlds exist for Indian women? How do they overlap and how do we represent them in their entire complexity and depth?

\section{References}


Kandiyoti, D. (1988) Bargaining with Patriarchy. Gender and Society, Vol.2 (3): 274-290.

Yuval-Davis, N. (1997) Gender and Nation. London: Sage.

To cite this article:

Mehta, Akanksha. (2016). The World Before Her: A Review. Feminist Dissent, (1), 139-143. Retrieved from:

http://journals.warwick.ac.uk/index.php/feministdissent/article/view/16 